\title{
Root inoculation of strawberry with the entomopathogenic fungi Metarhizium robertsii and Beauveria bassiana reduces incidence of the twospotted spider mite and selected insect pests and plant diseases in the field
}

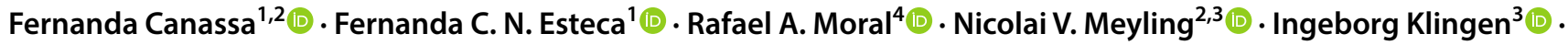 \\ Italo Delalibera' ${ }^{1}$ (1)
}

Received: 14 March 2019 / Revised: 28 June 2019 / Accepted: 5 August 2019 / Published online: 14 August 2019

(c) Springer-Verlag GmbH Germany, part of Springer Nature 2019

\begin{abstract}
The effect of inoculation of strawberry roots by two entomopathogenic fungal isolates, Metarhizium robertsii (ESALQ 1622) and Beauveria bassiana (ESALQ 3375), on naturally occurring arthropod pests and plant diseases was investigated in four commercial strawberry fields during two growing seasons in Brazil. Three locations represented open-field production while strawberries were grown in low tunnels at the fourth location. Population responses of predatory mites to the fungal treatments were also assessed. Plants inoculated by the fungal isolates resulted in significantly fewer Tetranychus urticae adults compared to control plants at all four locations. The mean cumulative numbers $\pm \mathrm{SE}$ of $T$. urticae per leaflet were: $M$. robertsii $(225.6 \pm 59.32), B$. bassiana $(206.5 \pm 51.48)$ and control $(534.1 \pm 115.55)$ at the three open-field locations, while at the location with tunnels numbers were: M. robertsii $(79.7 \pm 10.02), B$. bassiana $(107.7 \pm 26.85)$ and control (207.4 \pm 49.90$)$. Plants treated with $B$. bassiana had 50\% fewer leaves damaged by Coleoptera, while there were no effects on numbers of whiteflies and thrips. Further, lower proportions of leaflets with symptoms of the foliar plant pathogenic fungi Mycosphaerella fragariae and Pestalotia longisetula were observed in the M. robertsii (4.6\% and 1.3\%)- and B. bassiana $(6.1 \%$ and $1.3 \%)$-treated plots compared to control plots (9.8\% and 3.7\%). No effect was seen on numbers of naturally occurring predatory mites. Our results suggest that both isolates tested may be used as root inoculants of strawberries to protect against foliar pests, particularly spider mites, and also against foliar plant pathogenic fungi without harming naturally occurring and beneficial predatory mites.
\end{abstract}

Keywords Endophytic entomopathogenic fungi $\cdot$ Microbial control Plant-microbe interactions $\cdot$ Tetranychus urticae . Integrated pest management (IPM)

Communicated by E. Quesada-Moraga.

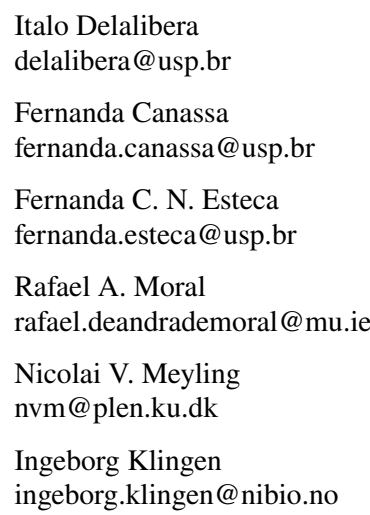

1 Department of Entomology and Acarology, "Luiz de Queiroz" College of Agriculture/University of São Paulo (ESALQ/USP), Piracicaba, São Paulo 13418-900, Brazil

2 Department of Plant and Environmental Sciences, University of Copenhagen, Thorvaldsensvej 40, 1871 Frederiksberg C, Denmark

3 Biotechnology and Plant Health Division, Norwegian Institute of Bioeconomy (NIBIO), NO-1431, P.O. Box 115, Ås, Norway

4 Department of Mathematics and Statistics, Maynooth University, Maynooth, Co. Kildare, Ireland 


\section{Key message}

- Few studies have investigated the potential of plants inoculated with entomopathogenic fungi as microbial control agents under natural field conditions.

- The first report of reduced Tetranychus urticae numbers on strawberry plants receiving root inoculation with the entomopathogenic fungi Metarhizium robertsii and Beauveria bassiana under commercial cultivation regimes.

- Reduction in foliar plant pathogenic fungi and no harmful effects on naturally occurring predatory mites were also observed.

- This represents a new tool and an innovative biocontrol strategy that may be implemented in IPM and organic strawberry production.

\section{Introduction}

Strawberry is an important fruit throughout the world, and in 2016, approximately 9.2 million tons of fruits were produced worldwide, with a yield of $22.690 \mathrm{~kg} \mathrm{ha}^{-1}$ (FAOSTAT 2018). Cultivated strawberry, Fragaria $\times$ ananassa (Duch; Rosales: Rosacea), is attacked by a large complex of arthropod pests and plant diseases that may reduce the yield (Solomon et al. 2001). The twospotted spider mite, Tetranychus urticae Koch (Acari: Tetranychidae), is an important pest of many crops throughout the world (Greco et al. 2005), including strawberries (Raworth 1986; Easterbrook et al. 2001; Solomon et al. 2001). Tetranychus urticae feed mainly on the underside of leaves, and this feeding may lead to reduced photosynthesis and increased transpiration as well as injection of phytotoxic substances when feeding on mesophyll and parenchyma plant cells (Sances et al. 1979, 1982; Attia et al. 2013). The feeding damage therefore decreases foliar and floral development causing reductions in quality and quantity of fruits (Rhodes et al. 2006).

Other important pest of strawberries worldwide includes the western flower thrips, Frankliniella occidentalis (Pergande) (Thysanoptera: Thripidae), which causes damage by the feeding of nymphs and adults resulting in flower abortion, fruit bronzing and malformation, and consequently yield loss (Solomon et al. 2001; Coll et al. 2007). Strawberries are also attacked by aphids of different species such as Chaetosiphon fragaefolli (Cockerell), Aphis forbesi Weed, Aphis gossypii Glover and Mizus persicae (Sulzer) (Hemiptera: Aphididae) (Solomon et al. 2001; Bernardi et al. 2015; Dara 2016). The whitefly Trialeurodes vaporariorum (Westwood) (Hemiptera: Aleyrodidae) is also a significant pest of strawberry crop in many regions (Solomon et al. 2001; Bernardi et al. 2015; Dara 2016). Moreover, Neopamera bilobata (Say) (Hemiptera: Rhyparochromidae) and the spotted wing fruit fly Drosophila suzukii (Matsumura) (Diptera: Drosophilidae) have recently invaded and caused economic losses in the production of many strawberry fields in Brazil (Kuhn et al. 2014; Andreazza et al. 2016). High incidence of plant pathogens, especially fungal pathogens, is another challenge faced by strawberry farmers in all producing countries and causes problems throughout the crop cycle, from the newly planted seedlings to the final fruit-producing stage (Garrido et al. 2011).

The main pest control strategy in strawberries throughout the world is the use of synthetic chemical pesticides (Solomon et al. 2001; Garrido et al. 2011). Dependency of these chemicals for pest control in strawberries is associated with undesirable effects on environment and human health (e.g., Attia et al. 2013; Barzman et al. 2015; Czaja et al. 2015). Outbreaks of T. urticae are often observed following continuous pesticide treatments (Klingen and Westrum 2007; Van Leeuwen et al. 2009, 2010) due to the emergence of pest resistance to the particular pesticides and destruction of the pests' natural enemies (Solomon et al. 2001; Sato et al. 2005). The use of invertebrate predators, parasitoids and microbial control agents in biological control is considered a sustainable alternative to synthetic chemical pesticides for control of arthropod pests (Garcia et al. 1988; Eilenberg et al. 2001). Except the application of predatory phytoseiid mites to control T. urticae, biological control is not widely used in strawberry production, and more development of macro- and microbial control agents and application strategies is therefore necessary (Solomon et al. 2001; Attia et al. 2013).

Entomopathogenic fungi within the order Hypocreales are used in microbial control, and many species are known to have a quite wide host range (Goettel et al. 1990; Rehner 2005). The species Beauveria bassiana (BalsamoCrivelli) Vuillemin (Cordycipitaceae) and several species of Metarhizium (Clavicipitaceae) have been considered promising microbial control agents in strawberries (Sabbahi et al. 2008; Castro et al. 2018) and may be implemented in programs for integrated pest management (IPM) (Hajek and Delalibera 2010). There are, however, constraints in the use of entomopathogenic fungi as microbial control agents, such as non-consistent effects against pests, short survival time of the fungal propagules in the environment, quality of commercial products, shelf life and costs (Lacey et al. 2015). These aspects are influenced by abiotic factors such as temperature, light intensity and quality, humidity and rainfall (Meyling and Eilenberg 2007; Castro et al. 2013) and by biotic factors such as multitrophic interactions with plants, 
invertebrates, other microorganisms and plant pathogens (Klingen and Haukeland 2006; Meyling and Eilenberg 2007; Meyling and Hajek 2010). In order to optimize pest control by entomopathogenic fungi, it is important to understand how these factors and their interactions affect the efficacy of the microbial control agent in question.

Recent studies have reported that entomopathogenic fungi in the Hypocreales, mainly Metarhizium spp. and Beauveria spp., may also interact with plants as endophytes (Vega 2008, 2018; Vega et al. 2009; Greenfield et al. 2016). Endophytic fungi are able to colonize the internal tissues of a host plant and cause no apparent negative effect on the plant (Carroll 1988; Stone et al. 2004; Vega 2008). This relationship between entomopathogenic fungi and their host plant may protect the plant against arthropod pests and plant diseases (Bing and Lewis 1991; Ownley et al. 2010; Jaber and Ownley 2018). Furthermore, endophytic fungi are protected inside the plant tissues from the effect of ambient abiotic factors (Vega 2008,2018 ) and the challenge of short survival time of fungal propagule in the environment due to abiotic factors may therefore be reduced. The mechanisms responsible for any plant protection capacity of plant-associated entomopathogenic fungi against arthropod pests and plant pathogens remain uncertain (Vidal and Jaber 2015; McKinnon et al. 2017).

Most of the published studies on entomopathogenic fungi as plant inoculants were carried out under controlled experimental conditions, and so far, only few studies have investigated the pest control potential of entomopathogenic fungi as inoculants of plants under field conditions while no field studies have evaluated effects against plant pathogens (Jaber and Ownley 2018). Field studies have been carried out with inoculation of common beans, Phaseolus vulgaris L. (Fabales: Fabaceae) with B. bassiana against Liriomyza leafminers (Diptera: Agromyzidae) (Gathage et al. 2016); of Sorghum bicolor L. (Moench) (Poales: Poaceae) with $B$. bassiana, Metarhizium robertsii Bisch., Rehner \& Humber, and Isaria fumosorosea (Wize) Brown \& Smith (Cordycipitaceae) (Mantzoukas et al. 2015); and of cotton Gossypium spp. (Malvales: Malvaceae) with B. bassiana against $A$. gossypii (Castillo-Lopez et al. 2014). These recent field studies report significant effects against foliar arthropod pests under field conditions, suggesting that implementation of entomopathogenic fungi as plant inoculants into outdoor IPM programs has a major potential (Lacey et al. 2015; Jaber and Ownley 2018). Few field studies have been conducted on strawberry. One study was conducted on soil drench granulate or root dipping application of Met52 $2^{\circledR}$ Metarhizium brunneum [reported as M. anisopliae (Metsch.) Sorokin] to strawberry against the soil living larvae of the black vine weevil Otiorhyncus sulcatus (Fabricius) (Coleoptera: Curculionidae) in a temperate region (UK), and it was suggested to be a potential strategy (Ansari and Butt 2013). Further, the persistence of locally adapted isolates of M. brunneum Petch and Beauveria pseudobassiana Rehner \& Humber applied as granulates close to strawberry roots was confirmed in studies in Norway (Klingen et al. 2015). However, none of these studies evaluated the potential of these fungi for improving plant productivity or controlling pests aboveground in strawberry.

The aim of the present study was therefore to evaluate the potential of two selected isolates of entomopathogenic fungi as root inoculants of strawberry plants for aboveground pest management under field conditions in Brazil. The fungal species used were $M$. robertsii and $B$. bassi$a n a$, and the origin of the isolates was Brazil. They were selected based on the ability to reduce T. urticae numbers on strawberry (F. Canassa, unpubl.) and on common beans $P$. vulgaris (Canassa et al. 2019), in greenhouse experiments. The effects on natural predatory mite populations were also assessed to evaluate the effect of the fungal inoculation strategy on natural enemies of T. urticae in the strawberry foliage. Further, prevalence of insect pests and important strawberry foliar pathogens was also monitored.

\section{Materials and methods}

\section{Fungal isolates}

Based on earlier efficacy studies (F. Canassa, unpubl.), two entomopathogenic fungal isolates $M$. robertsii ESALQ 1622 and B. bassiana ESALQ 3375, identified to species level by molecular techniques according to Rezende et al. (2015) and Rehner and Buckley (2005), were selected. Isolates were kept at $-80^{\circ} \mathrm{C}$ in the entomopathogen collection "Prof. Sérgio Batista Alves" in the "Laboratory of Pathology and Microbial Control of Insects" at Escola Superior de Agricultura "Luiz de Queiroz" at University of São Paulo (ESALQ/USP), Piracicaba, São Paulo, Brazil. The M. robertsii ESALQ 1622 isolate originated from soil of a corn

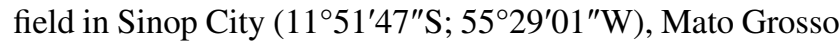
State, Brazil, and the B. bassiana ESALQ 3375 isolate was obtained from soil of a strawberry field in Senador Amaral City (22 $\left.33^{\prime} 12^{\prime \prime} \mathrm{S} ; 46^{\circ} 13^{\prime} 41^{\prime \prime} \mathrm{W}\right)$, Minas Gerais State, Brazil.

\section{Experimental setup}

The experiments were conducted in four different commercial strawberry fields (Fig. 1). The roots of the strawberry seedlings were immersed in one of the following treatments before planting: A) $M$. robertsii ESALQ 1622 in water $+0.05 \%$ Tween 80 ; B) B. bassiana ESALQ 3375 in water $+0.05 \%$ Tween 80 ; C) Water $+0.05 \%$ Tween 80 (control). A randomized block design was used in all four field experiments.

Three experiments were conducted in Atibaia City, São Paulo State, Brazil, from March to September 2018 
Fig. 1 Experimental field setup in open-field locations 1, 2 and 3 in Atibaia (1: $23^{\circ} 04^{\prime} 14.32^{\prime \prime} \mathrm{S} 46^{\circ} 40^{\prime} 58.2^{\prime \prime} \mathrm{W}$, 2: $23^{\circ} 04^{\prime} 33.5^{\prime \prime} \mathrm{S} 46^{\circ} 40^{\prime} 30.1^{\prime \prime} \mathrm{W}$, 3: $23^{\circ} 08^{\prime} 00.7^{\prime \prime} \mathrm{S} 46^{\circ} 37^{\prime} 04.5^{\prime \prime} \mathrm{W}$ ) and in low tunnel location 4 in Senador Amaral (22॰33'12.1'"S $\left.46^{\circ} 13^{\prime} 41.8^{\prime \prime} \mathrm{W}\right)$. Rows and area used for recording of data are indicated as a rectangle inside each bed
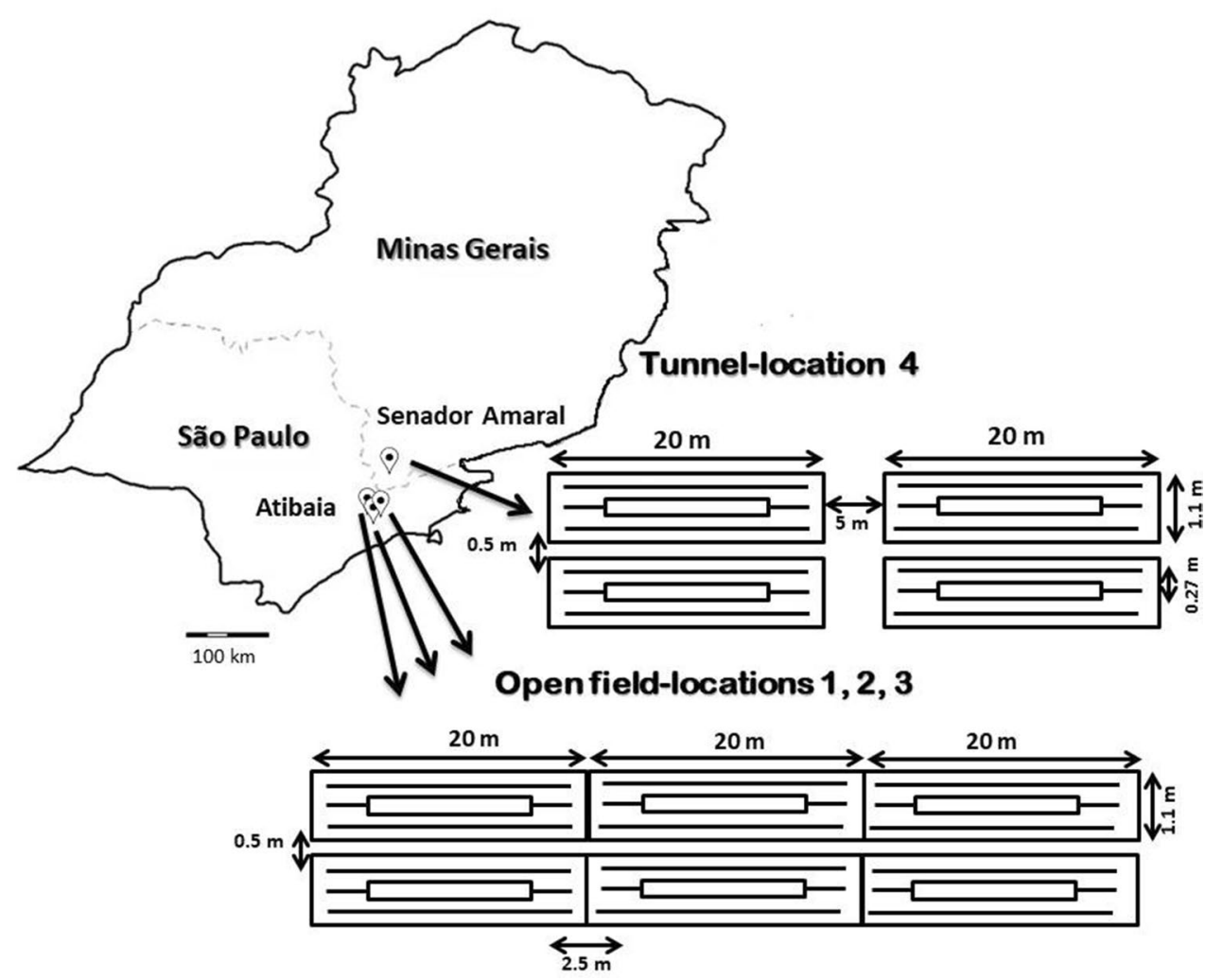

in three separate open commercial strawberry fields with black plastic mulching and drip irrigation. (Open-field locations 1, 2, 3 are shown in Fig. 1.) At all three locations, an experimental strawberry block was $60 \mathrm{~m}$ long ( $20 \mathrm{~m}$ for each treatment), $1.1 \mathrm{~m}$ wide and contained 600 plants (200 plants for each treatment). Experiments at location $1\left(23^{\circ} 04^{\prime} 14.32^{\prime \prime} \mathrm{S} ; 46^{\circ} 40^{\prime} 58.2^{\prime \prime} \mathrm{W}\right)$ and location 2 $\left(23^{\circ} 04^{\prime} 33.5^{\prime \prime} \mathrm{S} ; 46^{\circ} 40^{\prime} 30.1^{\prime \prime} \mathrm{W}\right)$ had 6 blocks (= strawberry beds), where the three treatments A), B) and C) were randomized inside each block, totaling 3.600 plants, while at location $3\left(23^{\circ} 08^{\prime} 00.7^{\prime \prime} \mathrm{S} ; 46^{\circ} 37^{\prime} 04.5^{\prime \prime} \mathrm{W}\right)$ there were 4 blocks (= strawberry beds), where the three treatments (A), (B) and (C) were also randomized inside each block, totaling 2.400 plants. Strawberry cultivars of locations 1, 2 and 3 were Camarosa (University of California, 1993), Camino real (University of California, 2001) and Oso grande (University of California, 1989), respectively. At these three locations, bare root strawberry plants (Fragaria $\times$ ananassa) were planted at the 4-leaf stage in three rows per bed with a distance of $0.27 \mathrm{~cm}$ between rows.

The experiment at location 4 was conducted in Senador Amaral City $\left(22^{\circ} 33^{\prime} 12.1^{\prime \prime} \mathrm{S} ; 46^{\circ} 13^{\prime} 41.8^{\prime \prime} \mathrm{W}\right)$, Minas Gerais State, Brazil, from July 2017 to January 2018, in low tunnels (short hoop structures covered with white plastic), with black plastic mulching and drip irrigation (tunnel location 4 in Fig. 1). This field experiment was established in 18 low tunnels representing four blocks, each with three strawberry beds of each treatment, i.e., 12 strawberry beds per treatment. Each bed was $20 \mathrm{~m}$ long, $1.1 \mathrm{~m}$ wide and contained 250 plants, totaling 3000 plants per treatment. At location 4 , bare root strawberry plants, cultivar Albion (University of California, 2006) were planted at the 4-leaf stage individually in three rows with a distance of $0.27 \mathrm{~cm}$ between rows.

\section{Preparation of fungal inoculum}

The two fungal isolates (M. robertsii ESALQ 1622 and $B$. bassiana ESALQ 3375) were retrieved from the $-80{ }^{\circ} \mathrm{C}$ culture collection and plated onto Petri dishes $(90 \times 15 \mathrm{~mm})$ containing $20 \mathrm{ml}$ Potato Dextrose Agar (PDA; Merck, Darmstadt, Germany). The cultures were then kept in darkness at $25{ }^{\circ} \mathrm{C}$ for 10 days until harvesting of conidia. This was done by adding $10 \mathrm{ml}$ sterile $0.05 \%$ Tween 80 (Oxiteno, São Paulo, Brazil) to the culture and scraping off the conidia with a sterile spatula. Conidial concentrations were estimated using a Neubauer hemocytometer (Merck, Darmstadt, Germany) and adjusted to $1 \times 10^{8}$ conidia $\mathrm{ml}^{-1}$. Later, $10 \mathrm{ml}$ of each suspension was inoculated with a pipette into individual polypropylene bags ( $35 \mathrm{~cm}$ length $\times 22 \mathrm{~cm}$ width) containing $300 \mathrm{~g}$ autoclaved $\left(121^{\circ} \mathrm{C}, 20 \mathrm{~min}\right)$ parboiled rice, inside an aseptic laminar flow chamber.

The fungus-inoculated rice kernels were mixed in the plastic bags and incubated in darkness at $25{ }^{\circ} \mathrm{C}$ for 10 days. The bags were gently shaken every 2 days to ensure evenly 
distributed fungal growth on rice kernels. Prior to use in the experiment, the conidial viability was checked by preparing a conidial suspension by adding $1 \mathrm{~g}$ of rice with sporulating fungi from the plastic bag to $10 \mathrm{ml}$ sterile $0.05 \%$ Tween 80 . From the third dilution, $150 \mu \mathrm{l}$ of the conidial suspension was transferred with a pipette onto PDA. The percentage of conidia germination was then evaluated according to Oliveira et al. (2015). Suspensions were only used if germination rates were higher than $95 \%$.

\section{Fungal inoculation of strawberry roots}

Rice kernels colonized with the two isolates $(M$. robertsii ESALQ 1622 and B. bassiana ESALQ 3375) were added into water plus $0.05 \%$ Tween 80 as described below. For the open-field experiments at locations 1,2,3, the original conidia concentration per gram of rice kernels for each isolate was estimated to $2.5 \times 10^{8} \mathrm{~g}^{-1}$ rice for $M$. robertsii and $1.3 \times 10^{9} \mathrm{~g}^{-1}$ rice for $B$. bassiana. The concentration was then adjusted to $1.5 \times 10^{12}$ conidia of $M$. robertsii on $3.0 \mathrm{~kg}$ rice and $B$. bassiana on $0.56 \mathrm{~kg}$ rice. The rice was mixed with 1001 of well water plus $50 \mathrm{ml} 0.05 \%$ Tween 80 , resulting in $1.5 \times 10^{6}$ conidia $\mathrm{ml}^{-1}$. The control consisted of 1001 of well water plus $50 \mathrm{ml} 0.05 \%$ Tween 80 . The final suspen-

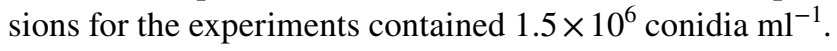

For the low tunnel experiment at location 4, the original conidia concentration per gram of rice kernels for each isolate was estimated to $1.8 \times 10^{8} \mathrm{~g}^{-1}$ rice for $M$. robertsii and $7.5 \times 10^{8} \mathrm{~g}^{-1}$ rice for $B$. bassiana. The concentration was then adjusted to $1.5 \times 10^{12}$ conidia of $M$. robertsii on $8.3 \mathrm{~kg}$ rice and $B$. bassiana on $2.0 \mathrm{~kg}$ rice. The rice was mixed with 7501 well water plus $375 \mathrm{ml} 0.05 \%$ Tween 80 , resulting in $2.0 \times 10^{6}$ conidia $\mathrm{ml}^{-1}$. The control consisted of 7501 of well water plus $375 \mathrm{ml} 0.05 \%$ Tween 80 .

Strawberry roots were inoculated by immersing the root system of each plant completely into the respective treatment suspensions for $2 \mathrm{~min}$. The inoculated plants were transported to the correct position in the rows inside plastic trays to avoid dripping suspension, and then, the plants were immediately planted into the row. The suspensions were continuously mixed with a wooden stick during the strawberry root inoculation to ensure homogenized concentrations.

\section{Evaluations: arthropod pests, natural enemies and plant pathogens}

All four field experiments were evaluated each 30 days for 6 months. However, the results obtained at location 4 (low tunnel experiment) are only reported up to 120 days after inoculation, because the producer applied a synthetic chemical pesticide at this time, which may have influenced the following observations at 150 and 180 days after inoculation.
In the open-field experiments at locations 1, 2 and 3, we observed 15 leaflets (= one leaf from a triplet) and 15 flowers representing 15 plants in each of the central rows of the strawberry beds as indicated in Fig. 1. In the low tunnel experiment at location 4 , we observed 15 leaflets $(=$ one leaf from a triplet) and 15 flowers from six plants (i.e., 2 or 3 leaflets per plant) in each of the central rows per strawberry bed as indicated in Fig. 1. Each leaflet was destructively sampled by hand and visually observed, and the arthropod pests were identified to species level and counted in the field.

The predatory mites were transferred to plastic vials (500 $\mathrm{ml}, 8.5 \mathrm{~cm}$ high, $10 \mathrm{~cm}$ diameter) containing 70\% ethanol and taken to the laboratory for identification by observing each specimen under microscope. Each predatory mite was collected with a fine brush from the vial with $70 \%$ ethanol and mounted in Hoyer's medium for identification to species by comparing their morphology with information from original descriptions and redescriptions provided in Rowell et al. (1978), Chant and Yoshida-Shaul (1991), Moraes et al. (2004) and Tixier et al. (2008).

Leaflets with characteristic symptoms of the plant pathogenic fungi Mycosphaerella fragariae Tul. (Lindau), Dendrophoma obscurans (Ell \& Ev.) and Pestalotia longisetula (Guba) were recorded, and the percentage of leaflets with the diseases was calculated.

\section{Evaluation of colonization of strawberry leaves and soil}

Sampling of strawberry leaves and soil adjacent to plant roots was done 180 days after inoculation to evaluate the presence of entomopathogenic fungi. One strawberry leaf (= three leaflets) was randomly and destructively collected from one plant per plot in the center row of each replicate plot treatment at each of the four locations. Collected leaves were placed in separate plastic bags and transferred to the laboratory for evaluation of endophytic colonization. The leaves were cut in sections of $4 \mathrm{~cm} \times 1 \mathrm{~cm}$, and they were then surface sterilized by following the method described by Greenfield et al. (2016). Three sections of leaves were plated on one Petri dish $(90 \times 15 \mathrm{~mm})$ with the following selective media: $20 \mathrm{ml}$ of PDA, $0.5 \mathrm{~g} \mathrm{l}^{-1}$ of cycloheximide, $0.2 \mathrm{~g} \mathrm{l}^{-1}$ of chloramphenicol, $0.5 \mathrm{~g} \mathrm{l}^{-1}$ of dodine (65\%) and $0.01 \mathrm{~g}^{-1}$ of crystal violet (Behie et al. 2015). The sterilization efficiency was confirmed by plating $100 \mu \mathrm{l}$ of the last rinsing water of the sterilization onto PDA (Parsa et al. 2013). Further, imprints of sterilized leaves were used as an additional method to confirm whether the sterilization was successful. This was done by gently pressing the leaf section with the cut edge onto the PDA medium (Greenfield et al. 2016) before placing sections in selective media plates. The Petri dishes were incubated at $25^{\circ} \mathrm{C}$ for 15 days before visually observed for fungal outgrowth of Metarhizium or 
Beauveria on each plant fragment. The frequency of occurrence was estimated as the number of plant fragments with entomopathogenic fungi present in relation to the total number of plant fragments.

Soil samples adjacent to plant roots were collected with a garden spade, from the same plants where leaves were sampled, without removing the plants. Then, soil with roots was placed into individual plastic bags and brought back to the laboratory. Here, the soil was mixed, and subsequently, $1 \mathrm{~g}$ was sampled and added to $10 \mathrm{ml}$ of sterile $0.05 \%$ Tween 80 and vigorously vortexed for $30 \mathrm{~s}$ and serially diluted into distilled water $+0.05 \%$ Tween 80 to obtain the following concentrations: $1 \times 10,1 \times 10^{-1}, 1 \times 10^{-2}$ and $1 \times 10^{-3}$. Petri dishes $(90 \times 15 \mathrm{~mm})$ containing selective agar medium as described above were divided into four equal quarter sections by marking the bottom part of the Petri dishes with a permanent marker. Then, $100 \mu \mathrm{l}$ from each soil dilution suspension was pipetted onto the selective media in each of the four sections. After the $100 \mu \mathrm{l}$ was dried up inside a laminar flow chamber, the Petri dishes were incubated in darkness at $25^{\circ} \mathrm{C}$ for 15 days, and the presence of Metarhizium or Beauveria was detected according to fungal growth morphology in each plate. The frequency of occurrence was estimated as the number of soil samples with entomopathogenic fungi in relation to the total number of samples.

\section{Statistical analysis}

We fitted Poisson generalized linear mixed models to the T. urticae counts obtained from locations 1, 2 and 3 (open field), including in the linear predictor the effects of block and different quadratic polynomials per each treatment and location combination over time (natural log-transformed) as fixed effects, and two random effects, namely the effect of bed (since observations taken over time on the same bed are correlated) and an observation-level random effect to model overdispersion. Hence, the maximal model included 32 fixed effects and 2 variance components, totaling 34 parameters. We then performed backwards selection, using likelihood ratio (LR) tests to assess the significance of the fixed effects. Treatments were compared by fitting nested models using grouped treatment levels and comparing them using LR tests; a significant test statistic means that the treatments cannot be grouped, as they are statistically different (see, e.g., Fatoretto et al. 2018). After model selection, the effects of proportion of occurrence of each plant pathogen species present (M. fragariae; P. longisetula; and D. obscurans), damage by Coleoptera (holes in the leaflets most likely caused by Colaspis spp.) and number of thrips (F. occidentalis) were added, separately, as covariates in the model and their significance was assessed using LR tests.

For the other variables observed in locations 1, 2 and 3 (open field), we worked with the aggregated values across all time points. The proportion of leaflets infected by plant pathogens present (M. fragariae, P. longisetula or D. obscurans) and the proportion of leaflets damaged by Coleoptera were analyzed by fitting quasi-binomial models with a logit link, including the effects of block, treatment, location and the interaction between treatment and location in the linear predictor. The number of thrips was analyzed by fitting quasi-Poisson models, also including the effects of block, treatment, location and the interaction between treatment and location in the linear predictor. Significance of effects was assessed using $F$ tests, since the dispersion parameter was estimated (Demétrio et al. 2014). Multiple comparisons were performed by obtaining the 95\% confidence intervals for the linear predictors.

For location 4 (low tunnel), Poisson generalized linear mixed models were fitted to the $T$. urticae counts, including in the linear predictor the effects of block and different intercepts and slopes per each treatment over time as fixed effects, and two random effects, namely the effect of bed (since observations taken over time on the same bed are correlated) and an observation-level random effect to model overdispersion. Here, the maximal model included 9 fixed effects and 2 variance components, totaling 11 parameters. As for the models fitted for locations 1, 2 and 3 (open field), we then performed backward selection, using likelihood ratio (LR) tests to assess the significance of the fixed effects. Treatments were compared the same way, by fitting nested models using grouped treatment levels and comparing them using LR tests. Again, after model selection, the effects of the proportion of occurrence of the number of pests present and plant pathogens were added, individually, as covariates in the model and their significance was assessed using LR tests.

For the other variables observed at location 4 (low tunnel), we worked with the aggregated values across all time points. The proportion of leaflets infected by plant pathogens was analyzed by fitting quasi-binomial models with a logit link, including the effects of block and treatment in the linear predictor. The number of cucurbit beetles, white flies, thrips and predatory mites was analyzed by fitting quasi-Poisson models, also including the effects of block and treatment in the linear predictor. Significance of effects was assessed using $F$ tests, and multiple comparisons were performed by obtaining the $95 \%$ confidence intervals for the linear predictors.

All analyses were carried out in R (R Core Team 2018). Goodness of fit was assessed using half-normal plots with a simulated envelope, using package hnp (Moral et al. 2017). Generalized linear mixed models were fitted using package lme4 (Bates et al. 2015). All plots were generated using package ggplot2 (Wickham 2009). 


\section{Results}

\section{Effects of M. robertsii and B. bassiana on T. urticae}

Root inoculation of strawberry plants with the two fungal treatments $(M$. robertsii ESALQ 1622 and B. bassiana ESALQ 3375) significantly influenced the number of $T$. urticae adults over the 6-month period (180 days) in openfield locations 1,2 and $3(\mathrm{LR}=30.31, d f=2, p<0.0001)$ (Fig. 2) and the low tunnel location $4(\mathrm{LR}=10.39, d f=2$, $p=0.0055$ ) (Fig. 3). No difference between plants inoculated with the two entomopathogenic fungi was seen in locations 1,2 and $3(\mathrm{LR}=0.07, d f=1, p=0.3092)$ nor in location $4(\mathrm{LR}=0.02, d f=1, p=0.8793)$.
There was no significant three-way interaction among open-field locations (1,2 and 3), treatment and time ( $\mathrm{LR}=4.06, d f=8, p=0.8516)$, nor significant two-way interactions between open-field locations (1,2 and 3) and treatment ( $\mathrm{LR}=0.69, d f=4, p=0.9524)$ and between treatment and time $(\mathrm{LR}=3.00, d f=4, p=0.5574)$. However, there was a significant interaction between location and time ( $\mathrm{LR}=49.91, d f=4, p<0.0001$ ), which means that the population dynamics of spider mites changed differently between the inoculated and control plants over time at each location, with a significantly higher number of adults on the control plants in the three locations $(\mathrm{LR}=30.31, d f=2$, $p<0.0001$ ) (Fig. 2). For the low tunnel location 4, there was no significant interaction between treatment and time (LR $=2.49, d f=2, p=0.2879)$; however, there were significant effects of time $(\mathrm{LR}=43.02, d f=1, p<0.0001)$ and
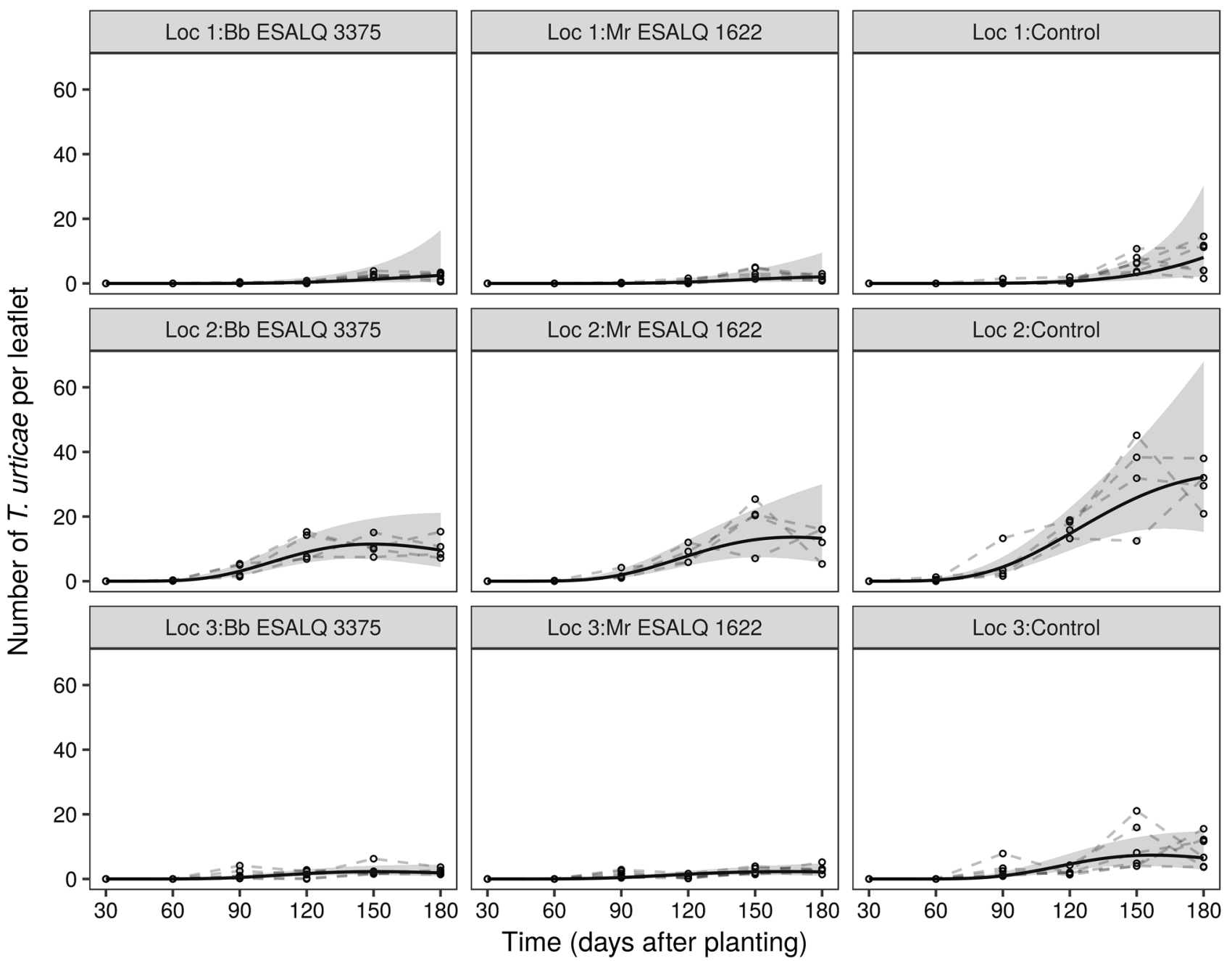

Fig. 2 Effect of inoculation of strawberry root with Beauveria bassiana $(\mathrm{Bb})$ isolate ESALQ 3375 or Metarhizium robertsii (Mr) ESALQ 1622 on numbers of adult Tetranychus urticae per leaflet 30, 60, 90, 120,150 and 180 days after inoculation, at the open-field locations 1,2 and 3 in Atibaia, São Paulo State, Brazil (Loc 1: $23^{\circ} 04^{\prime} 14.32^{\prime \prime}$ S $46^{\circ} 40^{\prime} 58.2^{\prime \prime} \mathrm{W}$, Loc 2: $23^{\circ} 04^{\prime} 33.5^{\prime \prime} \mathrm{S} 46^{\circ} 40^{\prime} 30.1^{\prime \prime} \mathrm{W}$, Loc 3: $23^{\circ} 08^{\prime} 00.7$ "S $\left.46^{\circ} 37^{\prime} 04.5^{\prime \prime} \mathrm{W}\right)$. The dots represent the observations; the solid lines are the fitted curves for the mean number of $T$. urticae per leaflet; and the gray areas represent $95 \%$ confidence intervals of the curves 


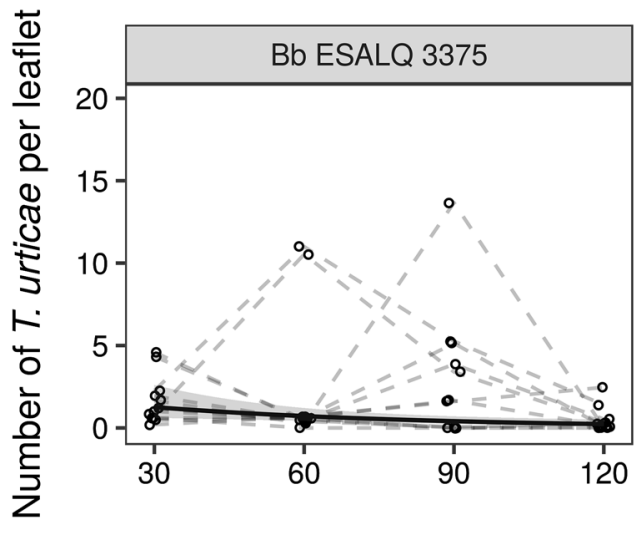

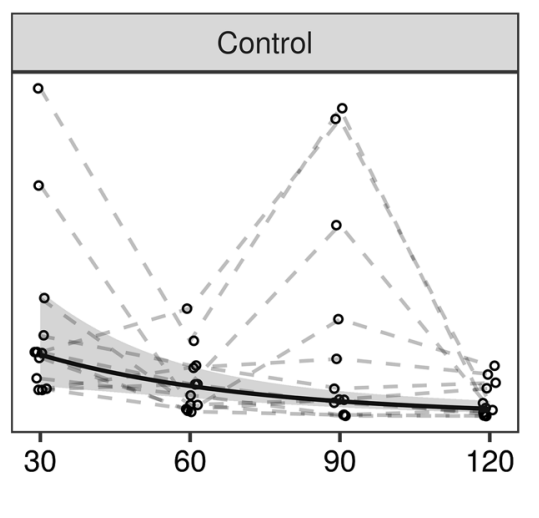

Fig. 3 Effect of inoculation of strawberry root with Beauveria bassiana $(\mathrm{Bb})$ isolate ESALQ 3375 or Metarhizium robertsii $(\mathrm{Mr})$ ESALQ 1622 on numbers of adult Tetranychus urticae per leaflet from $30,60,90$ and 120 days after inoculation at the low tunnel loca-

treatment $(\mathrm{LR}=10.39, d f=2, p=0.0055)$, and hence, there was a significantly higher number of $T$. urticae adults on the control plants at different times of evaluation, when compared to the two fungal treatments (Fig. 3).

There was no significant effect of the proportion of leaflets infected by the plant pathogens $M$. fragariae $(\mathrm{LR}=0.20$, $d f=1, p=0.6569), P$. longisetula $(\mathrm{LR}=1.89, d f=1$, $p=0.1693)$ and $D$. obscurans $(\mathrm{LR}=1.90, d f=1, p=0.1686)$ on the number of T. urticae in open-field locations 1,2 and 3. However, there was a significant effect of the proportion of leaves damaged by Coleoptera (holes in the leaflets most likely caused by Colaspis spp.) on the number of T. urticae ( $\mathrm{LR}=5.13, d f=1, p=0.0235)$, suggesting that numbers of T. urticae were lower on leaflets damaged by Coleoptera (estimate of -1.60 in the logit scale, with an associated standard error of 0.72 , indicating a negative relationship). tion 4 in Senador Amaral, Minas Gerais State, Brazil (22 $33^{\prime} 12.1^{\prime \prime} \mathrm{S}$ $\left.46^{\circ} 13^{\prime} 41.8^{\prime \prime} \mathrm{W}\right)$. The dots are the observations; the solid lines are the fitted curves for the mean number of T. urticae per leaflet; and the gray areas represent $95 \%$ confidence intervals

Besides, in locations 1, 2, 3 there was no significant interaction between numbers of $T$. urticae and thrips in flowers $(\mathrm{LR}=1.03, d f=1, p=0.3092)$. In low tunnel location 4 , there was no significant interaction between numbers of $T$. urticae and thrips in flowers $(\mathrm{LR}=0.73, d f=1, p=0.3929)$ or whiteflies $(\mathrm{LR}=3.74 d f=1, p=0.0532)$.

\section{Effects of $M$. robertsii and B. bassiana on other pests and diseases}

Damage caused by Coleoptera (holes in the leaflets) was significantly reduced on strawberry plants inoculated with B. bassiana ESALQ 3375 compared to control plants in open-field locations 1, 2 and 3 (Table 1). There was no significant interaction between location and treatment $\left(F_{4,34}=1.68, p=0.1767\right)$, but there was a significant effect

Table 1 Means \pm SE of proportion of leaflets damaged by Coleoptera (\%), cumulative number of thrips in flowers and proportion of leaflets longisetula and Mycosphaerella fragariae (\%) representing the differences in the open-field locations 1, 2 and 3, with summaries of generalized linear models

\begin{tabular}{|c|c|c|c|c|c|}
\hline \multicolumn{6}{|l|}{ Assessment $^{\mathrm{a}}$} \\
\hline \multirow[t]{2}{*}{ Treatments ${ }^{\mathrm{b}}$} & \multicolumn{5}{|l|}{ Locations $1,2,3$} \\
\hline & Coleoptera damage & No. of thrips & D. obscurans & P. longisetula & M. fragariae \\
\hline B. bassiana & $4.4 \pm 0.88 b$ & $24.5 \pm 4.67 \mathrm{a}$ & $2.7 \pm 1.23 \mathrm{a}$ & $1.3 \pm 0.37 b$ & $6.1 \pm 1.66 b$ \\
\hline M. robertsii & $6.6 \pm 1.15 \mathrm{ab}$ & $21.6 \pm 3.34 \mathrm{a}$ & $2.5 \pm 1.10 \mathrm{a}$ & $1.3 \pm 0.48 b$ & $4.6 \pm 1.35 b$ \\
\hline $\mathrm{H}_{2} \mathrm{O}+$ Tween 80 & $8.7 \pm 2.02 \mathrm{a}$ & $30.9 \pm 6.27 \mathrm{a}$ & $4.5 \pm 1.58 \mathrm{a}$ & $3.7 \pm 1.24 \mathrm{a}$ & $9.8 \pm 2.69 \mathrm{a}$ \\
\hline Test statistic & $F_{2,38}=4.17$ & $F_{2,38}=1.97$ & $F_{2,38}=1.02$ & $F_{2,38}=4.92$ & $F_{2,38}=5.84$ \\
\hline$p$ value & $p=0.0240$ & $p=0.1549$ & $p=0.3710$ & $p=0.0158$ & $p=0.0066$ \\
\hline
\end{tabular}

Separate analyses were performed for each response variable

${ }^{\mathrm{a}}$ Data (mean $\pm \mathrm{SE}$ ) followed by different letters within a column are significantly different (GLM, followed by post hoc Tukey test, $p<0.05$ )

${ }^{\mathrm{b}}$ Treatments included root inoculations of the entomopathogenic fungal isolates Beauveria bassiana ESALQ 3375 (B. bassiana), Metarhizium robertsii ESALQ 1622 (M. robertsii) and control treatment with $\mathrm{H}_{2} \mathrm{O}+0.05 \%$ Tween 80 
of location $\left(F_{2,40}=12.61, p<0.0001\right)$. The mean damage caused by Coleoptera $( \pm \mathrm{SE} \%)$ in each location was: location $1=10.68 \pm 1.57 \mathrm{a}$; location $2=3.89 \pm 0.84 \mathrm{~b}$; and location $3=4.54 \pm 1.15 \mathrm{~b}$.

There was no difference in the number of thrips in flowers between fungus-inoculated strawberry plants and the control plants in open-field locations 1, 2 and 3 (Table 1). There was no significant interaction between location and treatment $\left(F_{4,34}=0.47, p=0.7651\right)$, but there was a significant effect of location $\left(F_{2,40}=11.98, p=0.0001\right)$. The mean $\pm \mathrm{SE}$ $(\%)$ in each location was: location $1=27.59 \pm 4.28 \mathrm{~b}$; location $2=14.26 \pm 2.23 \mathrm{c} ;$ and location $3=40.09 \pm 6.78 \mathrm{a}$.

Although there was no difference in the proportion of leaflets ( $n=15$ leaflets per replicate) with symptoms of the plant pathogenic fungus $D$. obscurans in open-field locations 1,2 and $3\left(F_{2,38}=1.02, p=0.3710\right)$, the proportion of leaflets ( $n=15$ leaflets per replicate) with symptoms of $M$. fragariae and $P$. longisetula were significantly smaller on plants inoculated with $M$. robertsii ESALQ 1622 and $B$. bassiana ESALQ 3375 in all fields (Table 1). Besides, for $D$. obscurans, there was no significant interaction between location and treatment $\left(F_{4,34}=0.79, p=0.5386\right)$ and among the three open-field locations $\left(F_{2,40}=1.54, p=0.2300\right)$. For $P$. longisetula, there was also no significant interaction between location and treatment $\left(F_{4,34}=0.58, p=0.5676\right)$ and among the three open-field locations $\left(F_{2,40}=0.04, p=0.8433\right)$. Regarding the disease caused by $M$. fragariae, there was no significant interaction between location and treatment $\left(F_{4,34}=0.46, p=0.7640\right)$, but there was a significant effect of location $\left(F_{2,40}=39.84, p<0.0001\right)$. The mean \pm SE $(\%)$ in each location was: location $1=3.83 \pm 1.06$; location $2=14.20 \pm 1.90 ;$ and location $3=0.56 \pm 0.29$.

In low tunnel location 4 , in addition to T. urticae, the other major pests were whiteflies and thrips in flowers, but there was no difference in the number of any of these among the three treatments (Table 2). In this location, the density of pest was always very low and very few leaves with symptoms of plant pathogens were observed. The cumulative proportion of leaflets with symptoms of all the diseases (D. obscurans $+P$. longisetula $+M$. fragariae) is viewed in Table 2.

\section{Effects of $M$. robertsii and B. bassiana on predatory mites}

At open-field locations 1, 2 and 3, few arthropod natural enemies were observed, but at low tunnel location 4 there were many predatory mites, mainly of the species Neoseiulus californicus (McGregor) (Acari: Phytoseiidae). The numbers of these predatory mites at location 4 were not significantly different on plants inoculated with $M$. robertsii and $B$. bassiana, compared to the control $\left(F_{2,30}=0.04, p=0.9642\right)$. The mean $\pm \operatorname{SE}(\%)$ for the three
Table 2 Means \pm SE of cumulative number of whiteflies per leaflet and thrips per flower, and the mean \pm SE proportion of leaflets with symptoms of foliar pathogens (combined \% incidence of Dendrophoma obscurans + Pestalotia longisetula + Mycosphaerella fragariae) in the low tunnel location 4

\begin{tabular}{llll}
\hline Treatments $^{\mathrm{b}}$ & \multicolumn{2}{c}{ Assessment $^{\mathrm{a}}$} & \\
\cline { 2 - 4 } & Whiteflies & No. of thrips & Diseases \\
\hline B. bassiana & $6.6 \pm 1.70 \mathrm{a}$ & $1.9 \pm 5.33 \mathrm{a}$ & $0.5 \pm 0.31 \mathrm{a}$ \\
M. robertsii & $6.0 \pm 1.54 \mathrm{a}$ & $1.6 \pm 3.70 \mathrm{a}$ & $0.5 \pm 0.31 \mathrm{a}$ \\
$\mathrm{H}_{2} \mathrm{O}+$ Tween 80 & $5.9 \pm 1.38 \mathrm{a}$ & $1.8 \pm 2.91 \mathrm{a}$ & $1.2 \pm 0.42 \mathrm{a}$ \\
Test statistic & $F_{2,30}=0.07$ & $F_{2,30}=0.18$ & $F_{2 ; 30}=0.95$ \\
$p$ value & $p=0.9359$ & $p=0.8358$ & $p=0.3988$ \\
\hline
\end{tabular}

Summaries of separate statistical analyses for each response variable using generalized linear models are presented below

${ }^{\text {a }}$ Data $($ mean \pm SE) followed by different letters within a column are significantly different (GLM, followed by post hoc Tukey test, $p<0.05)$

${ }^{\mathrm{b}}$ Treatments included root inoculations of the entomopathogenic fungal isolates Beauveria bassiana ESALQ 3375 (B. bassiana), Metarhizium robertsii ESALQ 1622 (M. robertsii), and control treatment with $\mathrm{H}_{2} \mathrm{O}+0.05 \%$ Tween 80

treatments at location 4 was: $M$. robertsii $=14.3 \pm 3.83 ; B$. bassiana $=14.8 \pm 3.06$; and control $=13.6 \pm 2.57$ predatory mites per leaflet accumulated for all sampling dates.

\section{Colonization of $M$. robertsii and B. bassiana in strawberry leaves and soil}

Low colonization levels of the plants by both Metarhizium spp. and Beauveria spp. were observed 180 days after inoculation of strawberry roots. At open-field location 1, neither Metarhizium spp. nor Beauveria spp. were recovered on selective media from leaf samples, but Metarhizium spp. was found in all soil samples while Beauveria spp. was not recovered from soil. From samples collected at open-field location 2, 33.3\% (2 out of 6) of leaf sections and $16.7 \%$ (1 out of 6 ) of soil samples were found to harbor Beauveria spp., while Metarhizium spp. was recovered from $16.7 \%$ (1 out of 6 ) of the soil samples but not from the leaves. At open-field location 3, Beauveria spp. was recovered from $25 \%$ ( 1 out of 4 ) of leaves and soil samples while Metarhizium spp. was found in 75\% (3 out of 4) of the soil samples and not in leaves. At low tunnel location 4, Beauveria spp. was recovered from $41.7 \%$ (5 out of 12) of leaf samples and from $8.3 \%$ (1 out of 12) of soil samples. At this location, Metarhizium spp. was not recovered from the leaves, but the recovery from soil samples was $75 \%$ ( 9 out of 12). None of the leaves or samples from the 
control plots were found to contain any of the target fungi at any of the four locations.

\section{Discussion}

Our field experiment, replicated at four locations, shows that root inoculations of strawberry plants with $M$. robertsii ESALQ 1622 and B. bassiana ESALQ 3375 resulted in lower numbers of $T$. urticae adults compared to non-inoculated control plants. Few studies have investigated the potential of plant inoculated with entomopathogenic fungi as microbial control agents under natural field conditions (reviewed by Jaber and Ownley 2018; Vega 2018), and the present study is the first report of the effect on $T$. urticae numbers on strawberry plants inoculated with $M$. robertsii and B. bassiana evaluated in the field under commercial cultivation regimes. The two fungal isolates were previously found to reduce $T$. urticae populations on bean P. vulgaris (Canassa et al. 2019), and since our strawberry field study shows a similar effect, this may suggest that these isolates may be used as root inoculants of other crops to control T. urticae. Further, predatory mite populations were not negatively affected by strawberry plants inoculated with M. robertsii ESALQ 1622 and B. bassiana ESALQ 3375, indicating that adverse nontarget effects on arthropod natural enemies may be limited or non-existing.

The potential of B. bassiana as an endophyte for pest management has been reported in field studies with other crops. For example, Gathage et al. (2016) reported lower infestation levels of Liriomyza leafminers in bean leaves ( $P$. vulgaris) in a bean field experiment in Kenya where bean seeds had been inoculated with B. bassiana G1LU3 and Hypocrea lixii Patouillard (syn. Trichoderma lixii) F3ST1. Further, Castillo-Lopez et al. (2014) reported lower numbers of A. gossypii on cotton plants grown in the field in Texas, USA, from seeds inoculated with the commercial product Botanigard ${ }^{\circledR}$ (BioWorks Inc, Victor, $\mathrm{NY}$ ) based on the GHA strain of B. bassiana. Our field experiments also suggest that strawberry plants inoculated with $M$. robertsii ESALQ 1622 and B. bassiana ESALQ 3375 reduced the proportion of leaf damage caused by Coleopteran pests, while no effects on other pest damage, such as whiteflies or thrips in flowers, were observed. Mantzoukas et al. (2015) reported from field studies of Sorghum bicolor that B. bassiana and $M$. robertsii suppressed tunneling Sesamia nonagrioides (Lefébvre) (Lepidoptera: Noctuidae) larvae by $60 \%$ and $87 \%$ and increased larval mortality by $80 \%$ and $100 \%$, respectively, compared to control plants after spray inoculations of plants.

We also recorded a reduction in the prevalence of the foliar plant pathogenic fungi $M$. fragariae and $P$. longisetula in strawberry plants inoculated with B. bassiana ESALQ 3375 or M. robertsii ESALQ 1622. According to Jaber and Alananbeh (2018), only few studies have been conducted on the effects of plant inoculated with entomopathogenic fungi affecting plant pathogens, and so far, no field studies have been carried out. Jaber and Alananbeh (2018) reported, however, that sweet pepper Capsicum annum L. (Solanaceae) endophytically colonized with B. bassiana (NATURALIS) and M. brunneum (BIPESCO5) showed significantly reduced incidence and severity of three Fusarium species (F. oxysporum, F. culmorum and $F$. moniliforme) used in planta bioassays in controlled greenhouse settings with sterile soil. So far, B. bassiana is the most studied entomopathogenic fungal species against plant pathogens and it has been reported to protect tomato and cotton seedlings against the plant pathogens Rhizoctonia solani and Pythium myriotylum (Ownley et al. 2008). Furthermore, Sasan and Bidochka (2013) reported a 59.4\% inhibition of Fusarium solani $\mathrm{f}$. sp. phaseoli in bean, when co-cultured in pretreated sterile potting mixture with $M$. robertsii. In another study, the co-inoculation of wheat seeds with Metarhizium brunneum Petch and the mycoparasitic fungus Clonostachys rosea (Link) Schroers et al. (Hypocreales: Bionectriaceae) resulted in infections by $M$. brunneum in root-feeding Coleopteran larvae and provided protection against the plant pathogen F. culmorum (Keyser et al. 2016), but M. brunneum did not affect the plant pathogen individually. The present strawberry field study suggests that the tested isolates of $B$. bassiana and $M$. robertsii can provide long-term protection of strawberries against both arthropod pests and foliar pathogens using a single root application at the time of planting.

Our data also suggest that natural populations of predatory mites, most of them identified as $N$. californicus, remained unaffected on strawberry plant inoculated with $M$. robertsii ESALQ 1622 or B. bassiana ESALQ 3375. The field experiments therefore indicate a limited nontarget effect on arthropod natural enemies when the fungi are applied as root inoculants. Few studies have investigated the effects of plant-associated entomopathogenic fungi on arthropod natural enemies and mostly focus have been on effects on parasitoids (Bixby-Brosi and Potter 2012; Akutse et al. 2014; Jaber and Araj 2018). One of the few studies reporting on effects of plant-fungi interactions on predatory mites was by Schausberger et al. (2012), who showed that bean (P. vulgaris) colonized by the mycorrhizal fungus Glomus mosseae and infested with T. urticae changed the composition of herbivore-induced plant volatiles. This caused the fungus-inoculated plants to become more attractive to the predatory mites, Phytoseiulus persimilis Athias-Henriot (Acari: Phytoseiidae), than non-mycorrhizal plants. It was suggested that the predatory mites associated the plant response with the presence of prey (Patiño-Ruiz and Schausberger 2014) and hence showed a higher oviposition rate on these plants resulting in more efficient T. urticae suppression (Hoffmann et al. 2011). Canassa et al. (2019) reported in short-term leaf disk experiments that $P$. persimilis showed no difference in the predation rate on spider mites from inoculated plants with $B$. bassiana (ESALQ 3375) and M. robertsii (ESALQ 1622) compared to control plants. The use of $B$. bassiana (NATURALIS) 
and M. brunneum (BIPESCO5) as inoculants in sweet pepper combined with the aphid endoparasitoid Aphidius colemani Viereck (Hymenoptera: Braconidae) also indicated compatibility in control of $M$. persicae in a greenhouse study (Jaber and Araj 2018). In another recent study, González-Mas et al. (2019) reported that the numbers of A. gossypii parasitized by A. colemani were not influenced by whether the aphids had been feeding on seed-inoculated melon plants with $B$. bassiana (isolate EABb 01/33-Su) or not. Further, application of $B$. bassiana on melon leaves did not influence the number of aphids consumed by larvae of the lacewing, Chrysoperla carnea (Stephens) (Neuroptera: Chrysopidae), and C. carnea showed preference to feed on aphids reared on inoculated rather than control plants in a choice bioassay (González-Mas et al. 2019). All these findings indicate that plant inoculated with entomopathogenic fungi may be used in combination with parasitoids and predators to enhance the biocontrol efficacy of several plant pests in different crops.

In our study, we were able to recover Metarhizium and Beauveria from strawberry leaves and soil adjacent to the roots at the end of the experiment and cropping cycle, meaning 180 days (for locations 1, 2, 3) and 120 days (for location 4). The main aim of the present study was not to evaluate in depth the dynamics of endophytism of the inoculated fungal isolates using a close-to-practice inoculation method in strawberry production systems, and the use of commercial farm settings did not allow for repeated and complete destructive sampling of plant material. However, Castro et al. (2016) have previously reported the persistence in strawberry soil and rhizospheres in Brazil of the isolates $M$. anisopliae (ESALQ1037) and M. robertsii (ESALQ1426) for up to 12 months after soil drench application. Further, Klingen et al. (2015) report that two Norwegian isolates, one B. pseudobassiana and one M. brunneum, and an Austrian isolate of $M$. brunneum had long-term persistence (>1 year) in bulk soil and rhizosphere soil of strawberries in a semi-field experiment in Norway. It has previously been reported that $B$. bassiana is a more extensive colonizer of foliar tissues than Metarhizium spp., when seed inoculations were used, while Metarhizium spp. have been reported as almost exclusively colonizing the rhizosphere of various plant species (Ownley et al. 2008; Quesada-Moraga et al. 2009; Akello and Sikora 2012; Akutse et al. 2013; Behie et al. 2015), and similar results have been observed in our study. Although the observed effects of the inoculation on herbivore densities were consistent, endophytic colonization was not consistently detected in strawberry plants in our study. It has been previously reported that endophytic establishment may be influenced by several variables, such as host plant, fungal strain, environmental conditions, substrate and soil (Sánchez-Rodríguez et al. 2018). Moreover, previous research has showed that the establishment of entomopathogenic fungi within plant tissues may be transient (Garrido-Jurado et al. 2017) and the establishment success of fungal isolates is significantly reduced when inoculations are performed in natural soils (Parsa et al. 2018), as was the case in the present study. It should therefore be expected that end-point measurements of endophytic colonization will be limited in field studies, particularly over the 6-month time period.

Given that negative effects were broadly observed against both T. urticae and selected plant pathogens in the foliage after the single inoculation events of strawberry roots with isolates of either B. bassiana or M. robertsii, and considering the inconsistent re-isolation of fungi from leaf samples, it seems most likely that plant-induced defenses were responsible for the reductions, but this will require further studies to elucidate and conclude. It has been widely suggested that the mechanisms used by entomopathogenic fungi as plant associates and endophytes to antagonize plant pests or pathogens may result through the production of secondary metabolites by the associated fungus (Vidal and Jaber 2015; Yan et al. 2015; McKinnon et al. 2017; Jaber and Alananbeh 2018). Alternatively, another mechanism could be through induced systemic defense mechanisms of the inoculated plants, because the endophyte can be first recognized as a potential invader, which leads the plants to trigger its immune responses and consequently synthesize specific regulatory elements that may affect the arthropod pests and plant pathogen (Brotman et al. 2013; McKinnon et al. 2017).

In conclusion, the present study demonstrates that entomopathogenic fungi can be applied as root inoculants in commercial strawberry fields to simultaneously control important arthropod pests, particularly T. urticae, and plant pathogenic fungi. There were no indications that the inoculations of strawberry plant with the entomopathogenic fungal isolates tested had negative nontarget effects on naturally occurring predatory mites, particularly $N$. californicus. Hence, inoculation of strawberry plants with entomopathogenic fungi through root dipping may be used in combination with predatory mites for the control of $T$. urticae. This may represent a new tool and an innovative biological control strategy that could be implemented in IPM and organic strawberry production.

\section{Author contributions}

FC, IDJ, IK and NVM conceived and designed research. FC and FCNE conducted experiments. RAM analyzed data, prepared figures and wrote the statistical analysis section. FC, IK, IDJ and NV wrote the manuscript. All authors reviewed and approved the manuscript.

Acknowledgements Daniela Milanez Silva and Vitor Isaias da Silva are thanked for technical assistance. We thank the strawberry producers 
Claudio Donizete dos Santos, Rafael Maziero, Mario Inui and Maurício dos Santos for letting us perform the experiments in their fields. We also thank Dr. Fagoni Fayer Calegario for helping to find the farmers and for introducing them to us. Dr. Geovanny Barroso is thanked for helping with the predatory mite identification.

Funding This work was supported by the National Council for Scientific and Technological Development (CNPq) [Process No. 141373/2015-6] and by The Research Council of Norway through the SMARTCROP Project [Project Number 244526]. A 3-month student mission travel Grant to Norway was funded by CAPES (Project Number 88881.117865/2016-01) and SIU (Project Number UTF-2016-long-term-/10070).

\section{Compliance with ethical standards}

Conflict of interest The authors declare that they have no conflict of interest.

\section{References}

Akello J, Sikora R (2012) Systemic acropedal influence of endophyte seed treatment on Acyrthosiphon pisum and Aphis fabae offspring development and reproductive fitness. Biol Control 61:215-221. https://doi.org/10.1016/j.biocontrol.2012.02.007

Akutse KS, Maniania NK, Fiaboe KKM, Van Den Berg J, Ekesi S (2013) Endophytic colonization of Vicia faba and Phaseolus vulgaris (Fabaceae) by fungal pathogens and their effects on the life-history parameters of Liriomyza huidobrensis (Diptera: Agromyzidae). Fungal Ecol 6:293-301. https://doi.org/10.1016/j.funec o.2013.01.003

Akutse KS, Fiaboe KKM, Van den Berg J, Ekesi S, Maniania NK (2014) Effects of endophyte colonization of Vicia faba (Fabaceae) plants on the life-history of leafminer parasitoids Phaedrotoma scabriventris (Hymenoptera: Braconidae) and Diglyphus isaea (Hymenoptera: Eulophidae). PLoS ONE 9:e109965. https://doi. org/10.1371/journal.pone.0109965

Andreazza F, Haddi K, Oliveira EE, Ferreira JAM (2016) Drosophila suzukii (Diptera: Drosophilidae) arrives at Minas Gerais State, a main strawberry production region in Brazil. Fla Entomol 99:796798. https://doi.org/10.1653/024.099.0439

Ansari MA, Butt TM (2013) Influence of the application methods and doses on the susceptibility of black vine weevil larvae Otiorhynchus sulcatus to Metarhizium anisopliae in field-grown strawberries. Biocontrol 58:257-267. https://doi.org/10.1007/s1052 6-012-9491-x

Attia S, Grissa KL, Lognay G, Bitume E, Hance T, Mailleux AC (2013) A review of the major biological approaches to control the worldwide pest Tetranychus urticae (Acari: Tetranychidae) with special reference to natural pesticides. J Pest Sci 86:361-386. https://doi. org/10.1007/s10340-013-0503-0

Barzman M, Bàrberi P, Birch ANE, Boonekamp P, Dachbrodt-Saaydeh S, Graf B, Hommel B, Jensen JE, Kiss J, Kudsk P, Lamichhane JR, Messéan A, Moonen AC, Ratnadass A, Ricci P, Sarah JL, Sattin M (2015) Eight principles of integrated pest management. Agron Sustain Dev 35:1199-1215. https://doi.org/10.1007/s1359 3-015-0327-9

Bates D, Mächler M, Bolker B, Walker S (2015) Fitting linear mixedeffects models using lme4. J Stat Softw 67:1-28. https://doi. org/10.18637/jss.v067.i01

Behie SW, Jones SJ, Bidochka MJ (2015) Plant tissue localization of the endophytic insect pathogenic fungi Metarhizium and
Beauveria. Fungal Ecol 13:112-119. https://doi.org/10.1016/j. funeco.2014.08.001

Bernardi D, Botton M, Nava DE, Zawadneak MAC (2015) Guia para a identificação e monitoramento de pragas e seus inimigos naturais em morangueiro. Embrapa Clima Temperado, Brasília

Bing LA, Lewis LC (1991) Suppression of Ostrinia nubilalis (Hübner) (Lepidoptera: Pyralidae) by endophytic Beauveria bassiana (Balsamo) Vuillemin. Environ Entomol 20:1207-1211. https:// doi.org/10.1093/ee/20.4.1207

Bixby-Brosi AJ, Potter DA (2012) Endophyte-mediated tritrophic interactions between a grass-feeding caterpillar and two parasitoid species with different life histories. Arthropod Plant Interact 6:27-34. https://doi.org/10.1007/s11829-011-9163-2

Brotman YL, Landau U, Cuadros-Inostroza A, Takayuki T, Fernie AR, Chet I, Viterbo A, Willmitzer L (2013) Trichoderma-plant root colonization: escaping early plant defense responses and activation of the antioxidant machinery for saline stress tolerance. PLoS Pathog 9:e1003221. https://doi.org/10.1371/journ al.ppat. 1003221

Canassa F, Tall S, Moral RA, Lara IAR, Delalibera I Jr, Meyling NV (2019) Effects of bean seed treatment by the entomopathogenic fungi Metarhizium robertsii and Beauveria bassiana on plant growth, spider mite populations and behavior of predatory mites. Biol Control 132:199-208. https://doi.org/10.1016/j. biocontrol.2019.02.003

Carroll G (1988) Fungal endophytes in stems and leaves-from latent pathogen to mutualistic symbiont. Ecology 69:2-9. https ://doi.org/10.2307/1943154

Castillo-Lopez D, Zhu-Salzman K, Ek-Ramos MJ, Sword GA (2014) The entomopathogenic fungal endophytes Purpureocillium lilacinum (formerly Paecilomyces lilacinus) and Beauveria bassiana negatively affect cotton aphid reproduction under both greenhouse and field conditions. PLoS ONE 9:e103891. https:// doi.org/10.1371/journal.pone.0103891

Castro TR, Wekesa VW, Moral RA, Demétrio CGB, Delalibera I Jr, Klingen I (2013) The effects of photoperiod and light intensity on the sporulation of Brazilian and Norwegian isolates of Neozygites floridana. J Invertebr Pathol 114:230-233. https:// doi.org/10.1016/j.jip.2013.08.004

Castro T, Mayerhofer J, Enkerlib J, Eilenberg J, Meyling NV, Moral RA, Demétrio CGB, Delalibera I Jr (2016) Persistence of Brazilian isolates of the entomopathogenic fungi Metarhizium anisopliae and $M$. robertsii in strawberry crop soil after soil drench application. Agric Ecosyst Environ 233:361-369. https ://doi.org/10.1016/j.agee.2016.09.031

Castro T, Eilenberg J, Delalibera I Jr (2018) Exploring virulence of new and less studied species of Metarhizium spp. from Brazil for two-spotted spider mite control. Exp Appl Acarol 74:139146. https://doi.org/10.1007/s10493-018-0222-6

Chant DA, Yoshida-Shaul E (1991) Adult ventral setal patterns in the family Phytoseiidae (Acari: Gamasina). Int J Acarol 17(3):187199. https://doi.org/10.1080/01647959108683906

Coll M, Shakya S, Shouster I, Nenner Y, Steinberg S (2007) Decision-making tools for Frankliniella occidentalis management in strawberry: consideration of target markets. Entomol Exp Appl 122:59-67. https://doi.org/10.1111/j.1570-7458.2006.00488.x

Czaja K, Góralczyk K, Struciński P, Hernik A, Korcz W, Minorczyk M, Łyczewska M, Ludwicki JK (2015) Biopesticides-towards increased consumer safety in the European Union. Pest Manag Sci 71:3-6. https://doi.org/10.1002/ps.3829

Dara SK (2016) Managing strawberry pests with chemical pesticides and non-chemical alternatives. Int J Fruit Sci 16:1-13. https:// doi.org/10.1080/15538362.2016.1195311

Demétrio CGB, Hinde J, Moral RA (2014) Models for overdispersed data in entomology. In: Ferreira CP, Godoy WAC (eds) 
Ecological modelling applied to entomology, 1st edn. Springer, New York, pp 219-259

Easterbrook MA, Fitzgerald JD, Solomon MG (2001) Biological control of strawberry tarsonemid mite Phytonemus pallidus and two-spotted spider mite Tetranychus urticae on strawberry in the UK using species of Neoseiulus (Amblyseius) (Acari: Phytoseiidae). Exp Appl Acarol 25:25-36. https://doi. org/10.1023/A:1010685903130

Eilenberg J, Hajek A, Lomer C (2001) Suggestions for unifying the terminology in biological control. Biocontrol 46:387-400. https ://doi.org/10.1023/A:1014193329979

FAOSTAT (2018) Food and Agriculture Organization of the United Nations Statistics. http://faostat.org/. Accessed 10 Oct 2018

Fatoretto MB, Moral RA, Demétrio CGB, de Pádua CS, Menarin V, Rojas VMA, D'Alessandro CP, Delalibera I Jr (2018) Overdispersed fungus germination data: statistical analysis using R. Biocontrol Sci Technol 28:1034-1053. https://doi. org/10.1080/09583157.2018.1504888

Garcia R, Caltagirone LE, Gutierrez AP (1988) Comments on a redefinition of biological control. Bioscience 38:692-694. https ://doi.org/10.2307/1310871

Garrido C, Carbú M, Fernández-Acero FJ, González-Rodríguez VE, Cantoral JM (2011) New insights in the study of strawberry fungal pathogens. In: Husaini AM, Mercado JA (eds) Genes, genomes and genomics, 1st edn. Global Science Books, Takamatsu, pp 24-39

Garrido-Jurado I, Resquín-Romero G, Amarilla SP, Ríos-Moreno A, Carrasco L, Quesada-Moraga E (2017) Transient endophytic colonization of melon plants by entomopathogenic fungi after foliar application for the control of Bemisia tabaci Gennadius (Hemiptera: Aleyrodidae). J Pest Sci 90:319-330. https://doi. org/10.1007/s10340-016-0767-2

Gathage JW, Lagat ZO, Fiaboe KKM, Akutse KS, Ekesi S, Maniania NK (2016) Prospects of fungal endophytes in the control of Liriomyza leafminer flies in common bean Phaseolus vulgaris under field conditions. Biocontrol 61:741-753. https:// doi.org/10.1007/s10526-016-9761-0

Goettel MS, Poprawski TJ, Vandenverg JD, Li Z, Roberts DW (1990) Safety to nontarget invertebrates of fungal biocontrol agents. In: Laird M, Lacey LA, Davison EW (eds) Safety of microbial insecticides, 1st edn. CRC Press, Flórida, pp 209-232

González-Mas N, Cuenca-Medina M, Gutierrez-Sanchez F, QuesadaMoraga E (2019) Bottom-up effects of endophytic Beauveria bassiana on multitrophic interactions between the cotton aphid, Aphis gossypii, and its natural enemies in melon. J Pest Sci 92:1271-1281. https://doi.org/10.1007/s10340-019-01098-5

Greco NM, Pereyra PC, Guillade A (2005) Host-plant acceptance and performance of Tetranychus urticae (Acari: Tetranychidae). J Appl Entomol 130:32-36. https://doi.org/10.111 $1 /$ j.1439-0418.2005.01018.x

Greenfield M, Gomez-Jimenez MI, Ortiz V, Vega FE, Kramer M, Parsa S (2016) Beauveria bassiana and Metarhizium anisopliae endophytically colonize cassava roots following soil drench inoculation. Biol Control 95:40-48. https://doi.org/10.1016/j. biocontrol.2016.01.002

Hajek AE, Delalibera I Jr (2010) Fungal pathogens as classical biological control agents against arthropods. Biocontrol 55:147158. https://doi.org/10.1007/s10526-009-9253-6

Hoffmann D, Vierheilig H, Schausberger P (2011) Arbuscular mycorrhiza enhances preference of ovipositing predatory mites for direct prey-related cues. Physiol Entomol 36:90-95. https://doi. org/10.1111/j.1365-3032.2010.00751.x

Jaber LR, Alananbeh KM (2018) Fungal entomopathogens as endophytes reduce several species of Fusarium causing crown and root rot in sweet pepper (Capsicum annuиm L.). Biol Control 126:117-126. https://doi.org/10.1016/j.biocontrol.2018.08.007
Jaber LR, Araj SE (2018) Interactions among endophytic fungal entomopathogens (Ascomycota: Hypocreales), the green peach aphid Myzus persicae Sulzer (Homoptera: Aphididae), and the aphid endoparasitoid Aphidius colemani Viereck (Hymenoptera: Braconidae). Biol Control 116:53-61. https://doi.org/10.1016/j. biocontrol.2017.04.005

Jaber LR, Ownley BH (2018) Can we use entomopathogenic fungi as endophytes for dual biological control of insect pests and plant pathogens? Biol Control 116:36-45. https://doi.org/10.1016/j. biocontrol.2017.01.018

Keyser CA, Jensen B, Meyling NV (2016) Dual effects of Metarhizium spp. and Clonostachys rosea against an insect and a seedborne pathogen in wheat. Pest Manag Sci 72:517-526. https://doi. org/10.1002/ps.4015

Klingen I, Haukeland S (2006) The soil as a reservoir for natural enemies of pest insects and mites with emphasis on fungi and nematodes. In: Eilenberg J, Hokkanen HMT (eds) An ecological and societal approach to biological control, 1st edn. Springer, Dordrecht, pp 145-211

Klingen I, Westrum K (2007) The effect of pesticides used in strawberries on the phytophagous mite Tetranychus urticae (Acari: Tetranychidae) and its fungal natural enemy Neozygites floridana (Zygomycetes: Entomophthorales). Biol Control 43:222-230. https://doi.org/10.1016/j.biocontrol.2007.07.013

Klingen I, Westrum K, Meyling N (2015) Effect of Norwegian entomopathogenic fungal isolates against Otiorhynchus sulcatus larvae at low temperatures and persistence in strawberry rhizospheres. Biol Control 81:1-7. https://doi.org/10.1016/j.biocontrol .2014.10.006

Kuhn TMA, Loeck AE, Zawadneak MAC, Garcia MS, Botton M (2014) Parâmetros biológicos e tabela de vida de fertilidade de Neopamera bilobata (Hemiptera: Rhyparochromidae) em morangueiro. Pesq Agropec Bras 49:422-427. https://doi.org/10.1590/S0100 $-204 X 2014000600003$

Lacey LA, Grzywacz D, Shapiro-Ilan DI, Frutos R, Brownbridge M, Goettel MS (2015) Insect pathogens as biological control agents: back to the future. J Invertebr Pathol 132:1-41. https:// doi.org/10.1016/j.jip.2015.07.009

Mantzoukas S, Chondrogiannis C, Grammatikopoulos G (2015) Effects of three endophytic entomopathogens on sweet sorghum and on the larvae of the stalk borer Sesamia nonagrioides. Entomol Exp Appl 154:78-87. https://doi.org/10.1111/eea.12262

McKinnon AC, Saari S, Moran-Diez ME, Meyling NV, Raad M, Glare TR (2017) Beauveria bassiana as an endophyte: a critical review on associated methodology and biocontrol potential. Biocontrol 62:1-17. https://doi.org/10.1007/s10526-016-9769-5

Meyling NV, Eilenberg J (2007) Ecology of the entomopathogenic fungi Beauveria bassiana and Metarhizium anisopliae in temperate agroecosystems: potential for conservation biological control. Biol Control 43:145-155. https://doi.org/10.1016/j.biocontrol .2007 .07 .007

Meyling N, Hajek A (2010) Principles from community and metapopulation ecology: application to fungal entomopathogens. Biol Control 55:39-54. https://doi.org/10.1007/s10526-009-9246-5

Moraes GJ, McMurtry JA, Denmark HA, Campos CB (2004) A revised catalogue of the mite family Phytoseiidae. Zootaxa 434:1-494. https://doi.org/10.11646/zootaxa.434.1.1

Moral RA, Hinde J, Demétrio CGB (2017) Half-normal plots and overdispersed models in R: the hnp package. J Stat Softw 81:1-23. https://doi.org/10.18637/jss.v081.i10

Oliveira DGP, Pauli G, Mascarin GM, Delalibera I (2015) A protocol for determination of conidial viability of the fungal entomopathogens Beauveria bassiana and Metarhizium anisopliae from commercial products. J Microbiol Methods 119:44-52. https://doi. org/10.1016/j.mimet.2015.09.021 
Ownley BH, Griffin MR, Klingeman WE, Gwinn KD, Moulton JK, Pereira RM (2008) Beauveria bassiana: endophytic colonization and plant disease control. J Invertebr Pathol 3:267-270. https:// doi.org/10.1016/j.jip.2008.01.010

Ownley B, Gwinn K, Vega F (2010) Endophytic fungal entomopathogens with activity against plant pathogens: ecology and evolution. Biocontrol 55:113-128. https://doi.org/10.1007/s1052 6-009-9241-x

Parsa S, Ortiz V, Vega FE (2013) Establishing fungal entomopathogens as endophytes: towards endophytic biological control. J Vis Exp 74:e50360. https://doi.org/10.3791/50360

Parsa S, Ortiz V, Gómez-Jiménez MI, Kramer M, Vega FE (2018) Root environment is a key determinant of fungal entomopathogen endophytism following seed treatment in the common bean, Phaseolus vulgaris. Biol Control 116:74-81. https://doi.org/10.1016/j.bioco ntrol.2016.09.001

Patiño-Ruiz JD, Schausberger P (2014) Spider mites adaptively learn recognizing mycorrhiza-induced changes in host plant volatiles. Exp Appl Acarol 64:455-463. https://doi.org/10.1007/s1049 3-014-9845-4

Quesada-Moraga E, Muñoz-Ledesma F, Santiago-Alvarez C (2009) Systemic protection of Papaver somniferum L. against Iraella luteipes (Hymenoptera: Cynipidae) by an endophytic strain of Beauveria bassiana (Ascomycota: Hypocreales). Environ Entomol 38:723-730. https://doi.org/10.1603/022.038.0324

Raworth DA (1986) An economic threshold function for the twospotted spider mite, Tetranychus urticae (Acari: Tetranychidae), on strawberries. Can Entomol 118:9-16. https://doi.org/10.4039/ Ent1189-1

Rehner SA (2005) Phylogenetics of the insect pathogenic genus Beauveria. In: Vega FE, Blackwell M (eds) Insect fungal associations: ecology and evolution, 1st edn. University Press, New York, pp 3-27

Rehner SA, Buckley EP (2005) A Beauveria phylogeny inferred from ITS and EF1-a sequences: evidence for cryptic diversification and links to Cordyceps teleomorphs. Mycologia 97:84-98. https://doi. org/10.3852/mycologia.97.1.84

Rezende JM, Zanardo ABR, Lopes MD, Delalibera I Jr, Rehner SA (2015) Phylogenetic diversity of Brazilian Metarhizium associated with sugarcane agriculture. Biocontrol 60:495-505. https://doi. org/10.1007/s10526-015-9656-5

Rhodes EM, Liburd OE, Kelts C, Rondon SI, Francis RR (2006) Comparison of single and combination treatments of Phytoseiulus persimilis, Neoseiulus californicus, and Acramite (bifenazate) for control of twospotted spider mites in strawberries. Exp Appl Acarol 39:213-225. https://doi.org/10.1007/s10493-006-9005-6

Rowell HJ, Chant DA, Hansell R (1978) The determination of setal homologies and setal patterns on the dorsal shield in the family Phytoseiidae (Acarina: Mesostigmata). Can Entomol 110(8):859_ 876. https://doi.org/10.4039/Ent110859-8

Sabbahi R, Merzouki A, Guertin C (2008) Efficacy of Beauveria bassiana against the strawberry pests, Lygus lineolaris, Anthonomus signatus and Otiorhynchus ovatus. J Appl Entomol 132:151-160. https://doi.org/10.1111/j.1439-0418.2007.01248.x

Sances FV, Wyman JA, Ting IP (1979) Physiological responses to spider mite infestation on strawberries. Environ Entomol 8:711-714. https://doi.org/10.1093/ee/8.4.711

Sances FV, Toscano NC, Oatman ER, Lapre LF, Johnson MW, Voth V (1982) Reductions in plant processes by Tetranychus urticae (Acari: Tetranychidae) feeding on strawberry. Environ Entomol 11:733-737. https://doi.org/10.1093/ee/11.3.733

Sánchez-Rodríguez AR, Raya-Díaz S, Zamarreño ÁM, García-Mina JM, Campillo MC, Quesada-Moraga E (2018) An endophytic Beauveria bassiana strain increases spike production in bread and durum wheat plants and effectively controls cotton leafworm
(Spodoptera littoralis) larvae. Biol Control 116:90-102. https:// doi.org/10.1016/j.biocontrol.2017.01.012

Sasan RK, Bidochka MJ (2013) Antagonism of the endophytic insect pathogenic fungus Metarhizium robertsii against the bean plant pathogen Fusarium solani f. sp. phaseoli. Can J Plant Pathol 35:288-293. https://doi.org/10.1080/07060661.2013.823114

Sato ME, Da Silva MZ, Raga A, De Souza Filho MF (2005) Abamectin resistance in Tetranychus urticae Koch (Acari Tetranychidae): selection, cross-resistance and stability of resistance. Neotrop Entomol 34:991-998. https://doi.org/10.1590/S1519-566X200500 0600016

Schausberger P, Peneder S, Juerschik S, Hoffmann D (2012) Mycorrhiza changes plant volatiles to attract spider mite enemies. Funct Ecol 26:441-449. https://doi.org/10.111 1/j.1365-2435.2011.01947.x

Solomon MG, Jay CN, Innocenzi PJ, Fitzgerald JD, Crook D, Crook AM, Easterbrook MA, Cross JV (2001) Review: natural enemies and biocontrol of pests of strawberry in Northern and Central Europe. Biocontrol Sci Technol 11:165-216. https://doi. org/10.1080/09583150120035639

Stone JK, Polishook JD, White JRJ (2004) Endophytic fungi. In: Mueller G, Bills GF, Foster MS (eds) Biodiversity of fungi: inventory and monitoring method, 1 st edn. Elsevier, USA, pp 241-270

R Core Team (2018) R: a language and environment for statistical computing. R Foundation for Statistical Computing, Vienna, Austria. https://www.R-project.org/. Accessed 2 Nov 2018

Tixier M-S, Guichou S, Kreiter S (2008) Morphological variation in the biological control agent Neoseiulus californicus (McGregor) (Acari: Phytoseiidae): consequences for diagnostic reliability and synonymies. Invertebr Syst 22:453-469. https://doi.org/10.1071/ IS07052

Van Leeuwen T, Vontas J, Tsagkarakou A (2009) Mechanisms of acaricide resistance in the two spotted spider mite Tetranychus urticae. In: Ishaaya I, Horowitz AR (eds) Biorational control of arthropod pests, 1st edn. Springer, The Netherlands, pp 347-393

Van Leeuwen T, Vontas J, Tsagkarakou A, Dermauwa W, Tirry L (2010) Acaricide resistance mechanisms in the two-spotted spider mite Tetranychus urticae and other important Acari: a review. Insect Biochem Mol Biol 40:563-572. https://doi.org/10.1016/j. ibmb.2010.05.008

Vega FE (2008) Insect pathology and fungal endophytes. J Invertebr Pathol 98:277-279. https://doi.org/10.1016/j.jip.2008.01.008

Vega FE (2018) The use of fungal entomopathogens as endophytes in biological control: a review. Mycologia 110:4-30. https://doi. org/10.1080/00275514.2017.1418578

Vega FE, Goettel MS, Blackwell M, Chandler D, Jackson MA, Keller S, Koike M, Maniania NK, Monzón A, Ownley BH, Pell JK, Rangel DEN, Roy HE (2009) Fungal entomopathogens: new insights on their ecology. Fungal Ecol 2:149-159. https://doi. org/10.1016/j.funeco.2009.05.001

Vidal S, Jaber LR (2015) Entomopathogenic fungi as endophytes: plant-endophyte-herbivore interactions and prospects for use in biological control. Curr Sci 109:46-54

Wickham H (2009) ggplot2: elegant graphics for data analysis. Springer, New York

Yan J, Broughton S, Yang S, Gange A (2015) Do endophytic fungi grow through their hosts systemically? Fungal Ecol 13:53-59. https://doi.org/10.1016/j.funeco.2014.07.005

Publisher's Note Springer Nature remains neutral with regard to jurisdictional claims in published maps and institutional affiliations. 